\title{
ДАНІ НЕЙРОНАУК У ДОСЛІДЖЕННІ ПРИРОДНОМОВНОЇ КАТЕГОРИЗАЦІї
}

\author{
ВАСИЛЬ СТАРКО \\ Східноєвропейський національний університет імені Лесі Українки, \\ Луцьк - Україна \\ DANE NAUK NEUROLOGICZNYCH W BADANIU \\ NATURALNEJ KATEGORYZACJI JĘZYKOWEJ \\ WASYL STARKO \\ Wschodnioeuropejski Uniwersytet Narodowy im. Łesi Ukrainki, \\ Łuck - Ukraina
}

STRESZCZENIE. W artykule omówiono najważniejsze wyniki badań mózgu człowieka dotyczące językowej kategoryzacji świata. Stwierdzono, że istnieją podstawy uzasadniające korzystanie osób mówiących z wielorakich strategii kategoryzacji. Z tego punktu widzenia autor opisuje model kategoryzacji barw na materiale nazewnictwa kolorów w języku ukraińskim.

\section{NEUROSCIENCE DATA IN THE STUDY OF NATURAL-LANGUAGE CATEGORIZATION}

\section{VASYL STARKO \\ Lesya Ukrainka Eastern European National University, Lutsk — Ukraine}

ABSTRACT. The article analyzes some of the most important results of human brain studies concerning linguistic categorization of the world. It is shown that there are valid reasons to believe that speakers use multiple categorization strategies. In this light, the author describes a model of colour categorization involving Ukrainian colour names.

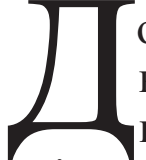

ослідження нейронних структур мозку відіграє дедалі більшу роль у лінгвістиці. Новітні методи вивчення роботи нейронного субстрату мозку в реальному часі відкрили не просто новий напрямок, а цілий вимір досліджень й спричинилися до експоненційного зростання досліджень нейронної архітектури мовних функцій. Завдання нашої розвідки полягає в 3'ясуванні внеску нейронаук до лінгвістичних досліджень природномовної категоризації. Це питання має тим більшу актуальність, що заторкує глибинні аспекти зв’язку мови й мислення й може привести до важливих висновків в інших ділянках мовних студій. Нас насамперед цікавитиме питання стратегій, чи процедур, категоризації за даними нейродосліджень. У порядку ілюстрації коротко розглянемо основні українські колоративи на позначення синьої частини спектру.

Насамперед варто зазначити, що нейронауки дають змогу по-новому підійти до деяких задавнених проблемних питань лінгвістики й зокрема природномовної категоризації. Це передусім пов'язано з усвідомленням особливостей нейронної організації мозку. Мозок - складна мережа сполучених нейронів, тому будь-які ментальні явища, як-от категорії й концепти, мають мере-
} 
жеву природу на рівні нейронного субстрату. За певних умов нейродослідження дають змогу зняти або переформулювати питання, сформульовані в межах суто аналітичної науки. Наприклад, у лінгвістиці відоме протиставлення класичної моделі категоризації з властивим їй бінарним членством (об'єкт або входить до класичної категорії, або не входить) та альтернативних моделей, що передбачають „градуальне” членство. Виявляється, що таке протиставлення дещо оманливе, позаяк обидві властивості реалізовано в єдиному механізмі роботи нейронних мереж: ступінь активації мережі чи іiі ділянки має градуальний характер, але існує поріг активації, що визначає, чи буде активований наступний нейрон у мережі. Інакше кажучи, в межах однієї категорії можна спостерігати класичні й некласичні ефекти, а та сама категорія може поставати як „традиційна" (коли категорійна належність спирається на сукупність необхідних і достатніх ознак) i ,розмита” (коли наявна польова структура).

Довгий час в історії когнітивних наук панувало уявлення, що людина категоризує за одним принципом. На його пошуки й були скеровані зусилля дослідників. Однак нещодавній прорив у когнітивній нейронауці привів до важливого відкриття: було отримано широкий і переконливий масив даних, які вказують на те, що людина користується більше, ніж однією системою засвоєння категорій ${ }^{1}$. На зміну унітарним підходам прийшов множинний підхід, що визнає наявність різних стратегій категоризації. Новітні дослідження в цій галузі відштовхуються вже від тези про наявність кількох функційно відмінних на нейронному й когнітивному рівнях систем². Сьогодні навряд чи хтось заперечуватиме, що до різних типів категорій люди постійно застосовують відмінні категоризаційні процедури. Наприклад, визначення числа як парного чи непарного спирається, без сумніву, на ознаку подільності на 2 (що становить категоризаційне правило), а звучання кларнета й скрипки розпізнають за подібністю до раніше даних у досвіді екземплярів (у цьому разі звукових образів) обох категорій, а не за певним правилом.

Набагато важливіші імплікації має питання про те, чи застосовує людина множинні категоризаційні механізми до того самого об'єкта. Наприклад, у відомому експерименті Л. Ріпса ${ }^{3}$ було показано, що людина може застосовувати різні процедури (принципи) категоризації до того самого об'єкта залежно від настанов. Учасникам дали опис „круглий об'єкт діаметром у два дюйми” й попросили скатегоризувати описаний об'єкт, зарахувавши до однієї з двох категорій: 25-центові монети або піци. Коли учасникам сказали, що лише одна відповідь правильна, це спонукало їх скористатися правилом, і вони зарахували об'єкт до піц, а не до монет, бо його діаметр явно більший, ніж може бути в монети. Коли ж респондентів попросили оцінити загальну подібність об'єкта до представників обох категорій, то відповіді розділилися.

Інші науковці пішли ще далі й спробували продемонструвати, що мовці в нормі паралельно й одночасно застосовують різні стратегії до тих самих об'єктів. Наприклад, в одному експерименті ${ }^{4}$ було використано дві штучні кате-

${ }^{1}$ E. E. S mith, M. Grossman, Multiple systems of category learning, [in:] „Neuroscience and Biobehavioral Reviews" 2008, No. 32, pp. 249-264; F. G. A s h by, W. T. Maddox, Human category learning 2.0, [in:] „Annals of the New York Academy of Sciences” 2011, No. 1224, pp. 147-161.

${ }^{2}$ F. G. As hby, W. T. Maddox, Ibidem.

${ }^{3}$ L. J . Rip s, Similarity, typicality, and categorization, [in:] S. Vosniadou, A. Ortony (eds.): Similarity and Analogical Reasoning, Cambridge 1989, pp. 21-59.

${ }^{4} \mathrm{~S}$. W. A lle n, L. R. B r o o k s, Specializing the operation of an explicit rule, [in:] ,Journal of Experimental Psychology" 1991, No. 120, pp. 3-19. 
горії уявних намальованих тварин. Їх можна було скатегоризувати за простим правилом (наявність двох із п'яти бінарних ознак) або за подібністю. Тварин було сконструйовано так, що певна їхня частина становила перехідні випадки: за правилом вони потрапляли до однієї категорії, а за подібністю - до іншої. Учасники, яким дали інструкцію застосовувати для категоризації правило, тим не менш досить часто покладалися на зв'язки подібності під час класифікації перехідних екземплярів, зараховуючи їх до іншої, „неправильної” категорії. Іншими словами, всупереч настанові на категоризацію за правилами в них мимоволі спрацьовував механізм категоризації за подібністю. Кількість таких помилок становила $45 \%$, i час реакції був більший, ніж для однозначних екземплярів. Таким чином, було встановлено, що обидва категоризаційні механізми працювали паралельно; кожен давав свої результати, і на етапі виведення відбувався вибір відповіді. Суперечливі дані призводили до затримки реакції, а згідні дані оброблялися швидше, тобто суб'єкти постійно застосовували дві стратегії одночасно, а на кінцевому етапі відбувався вибір однієї реакції. Попри різні модифікації побудови експерименту з метою зменшити ймовірність відходу від застосування правил, категоризація за подібністю збереглася, що свідчить про глибоку вкоріненість цього механізму.

Дані нейровізуалізаційних досліджень підтверджують паралельну роботу різних систем категоризації. За вибір і перемикання між ними відповідають окремі ділянки передлобової частки кори головного мозку5. Якщо результати роботи цих систем збігаються, то категоризація пришвидшується, виникає ефект праймінгу. Якщо ж вони суперечливі, то реакція затримується - в такому разі говорять про конкуренцію систем категоризації.

Накопичення такого роду експериментальних даних привело до низки узагальнень ${ }^{6}$ :

- до процесів категоризації в мозку людини залучаються різні нейронні системи, залежно від типу категорії й способу іï використання;

- представлення категорій розподілено по зонах мозку, вони охоплюють різні нейронні системи. До виконання одного завдання з категоризації може залучатися низка відмінних систем;

- опанування категорій вимагає компромісу між узагальненням попереднього досвіду й запам'ятовуванням конкретних об'єктів чи подій;

- у у вивченні категорій перехрещуються й накладаються імпліцитна й експліцитна, декларативна й недекларативна системи пам'яті;

- до актуальних завдань належить 3'ясування того, які системи вивчення категорій залучаються в конкретних ситуаціях, залежно від яких чинників і як вони взаємодіють.

У межах парадигми, в якій стратегії категоризації пов'язують із різними типами пам'яті, було виокремлено низку категоризаційних систем, однак бракує одностайності щодо їхньої суті й кількості. Найбільш дослідженим у нейрокогнітивній літературі $є$ механізм категоризації за правилами з використанням дискретних ознак. Його пов'язують із робочою пам'яттю, що відповідає за тимчасове зберігання правил та результатів звіряння ознак, із яких складаються правила, з ознаками категоризованих об’єктів. Цей механізм експліцитний, тобто менш-більш доступний свідомості. Процес категоризації логічний і прозорий, він може охоплювати перевірку гіпотези, спосіб спроб і помилок, виведення

${ }_{6}^{5}$ F. G. Ashby, W. T. Maddox, Ibidem.

${ }^{6}$ C. A. S eger, Category Learning in the Brain, [in:] „Annual Review of Neuroscience” 2010, No. 33, pp. 203-19. 
й перевірку певної „теорії’, застосування певної усвідомленої стратегії, а також запам'ятовування назви відповідної категорії для кожного пред’явленого стимулу. Опанування категорією може відбуватися одномоментно - коли людина сама вловлює або їй повідомляють правило, що окреслює категорію. Найпростішим прикладом може бути сортування предметів на, скажімо, квадратні й округлі. В інших випадках правила можуть охоплювати більшу кількість ознак. Загалом швидкість вивчення категорії залежить від того, скільки часу знадобиться на формулювання коректного правила. Зворотний зв'язок (інформація про правильність категоризації того чи того об'єкта) не є обов'язковий. Особливістю категоризації за правилами є наявність чітких, дискретних ознак, що стають об’єктом вибіркової уваги систем мозку в процесі категоризації об'єктів. При цьому деякі науковці наголошують, що ці ознаки мають легко вербалізуватися ${ }^{7}$, а інші - що вони мають легко виокремлюватися 3 об'єктів ${ }^{8}$. Цей механізм категоризації називають також декларативним, бо він пов'язаний iз декларативною пам'яттю - усвідомленою, пристосованою до миттєвого запам'ятовування. Нейронним субстратом системи категоризації за правилами вважають (хоча й з деякими розбіжностями) передлобову кору (пов’язану 3 робочою пам'яттю й виконавчими функціями мозку), гіпокамп, медіальноскроневі відділи кори9. Зафіксовано також підвищену активацію тім'яних ділянок кори головного мозку ${ }^{10}$ та смугастого тіла ${ }^{11}$, що, однак, залучено до роботи й інших систем категоризації.

Інший значний категоризаційний механізм спирається на подібність. Тут погляди дослідників розходяться: деякі вважають його окремою імпліцитною системою $^{12}$, а інші виокремлюють експліцитну та імпліцитну категоризацію за подібністю ${ }^{13}$. Категоризація за подібністю має розмаїті застосування. Імпліцитну категоризацію пов'язують із імпліцитною довготерміновою пам'яттю, яку окреслюють переважно через негативні характеристики - відсутність активації в різних зонах. Через це не виключено існування кількох іiі різновидів. Експліцитна категоризація за подібністю спирається на гештальти, загальні цілісні образи об'єктів. У експериментах переважно досліджують перцептивні образи, хоч експліцитна категоризація за подібністю може стосуватися й семантичних категорій. У межах цього типу лежить порівняння з екземпляром і порівняння $з$ прототипом категорії. Нейронний субстрат експліцитної категоризації за подібністю - ділянки медіальної скроневої частки кори головного мозку ${ }^{14}$.

На підтвердження існування цих відмінних категоризаційних систем зібрано вагомий масив доказів:

- відмінність профілів тверджень про категоризацію. Учасники експериментів, які застосовували правила, подавали категоричні судження (належить або не належить до категорії), а в разі категоризації за подібністю профіль мав градуальний характер;

- категоризаційні дефекти серед пацієнтів із хворобою Альцгеймера та 3 кортико-базальною дегенерацією мають вибірковий характер: у них поруше-

${ }^{7}$ F. G. Ashby, W. T. Maddox, Ibidem.

${ }^{8}$ E. E. Smith, M. Grossman, Ibidem.

${ }^{9}$ F. G. Ashby, W. T. Maddox, Ibidem.

${ }^{10}$ E. E. Smith, M. Grossman, Ibidem.

${ }^{11}$ F. G. A shby, Categorization, Neural Basis, [in:] H. Pashler (ed.): The Encyclopedia of the Mind, Oaks, CA 2013, pp. 130-134.

${ }^{12}$ F. G. Ashby, W. T. Maddox, Ibidem.

${ }^{13}$ E. E. Smith, M. Grossman, Ibidem.

${ }^{14}$ Ibidem. 
на категоризація за правилами, але не за подібністю. Такі результати отримано на основі нових перцептивних категорій та природних семантичних категорій.

- нейровізуалізаційні дослідження на матеріалі нових категорій та природних категорій показали подвійну дисоціацію (англ. double dissociation), тобто було виявлено специфічні ділянки, що активуються під час використання правил (зокрема передлобові зони), і специфічні ділянки, що корелюють із категоризацією за подібністю (зокрема тім'яні зони, що відповідають за інтеграцію перцептивних ознак) $)^{15}$.

Категоризація нових, незнаних об'єктів (засвоєння нових категорій) відбувається набагато рідше, ніж автоматична категоризація (операції з відомими об'єктами), однак перший різновид досліджено набагато краще. С вагомі підстави вважати, що нейронні механізми початкового вивчення нових категорій та автоматичного оброблення добре засвоєних категорій відрізняються ${ }^{16}$. Цю відмінність яскраво ілюструє відомий факт: людина поволі вивчає категорію, а потім може швидко звертатися до неї в „,автоматичному режимі”. Процеси утворення категорії й володіння категорією різняться на когнітивному й нейронному рівнях. Наприклад, люди 3 хворобою Паркінсона мають порушення процесів опанування нових категорій, але зберігають здатність послуговуватися старими, відомими категоріями. Масив недавніх досліджень також наводить на думку про те, що в процесі автоматизації категоризації відбувається перерозподіл ролей: спочатку передлобова частка та смугасте тіло відіграють ключову роль, а $з$ часом, в міру узвичаєння, ще до їхнього включення починають реагувати передрухова та рухова зони. Інакше кажучи, контроль переходить від ділянок, що відповідають за початкову категоризацію, до суто кортикальних мереж, які поєднують ділянки сенсорних асоціацій, що відповідають за перцепцію стимулу, та передрухові / рухові зони, які відповідають за моторну відповідь ${ }^{17}$. Для узвичаєної категоризації, але не для вивчення категорій, важливі асоціативні зони кори головного мозку, як-от нижньоскронева ділянка. Вона відповідає за високорівневу репрезентацію візуальних стимулів, і з нею пов'язані деякі категорієзалежні агнозії, тобто неспроможність розпізнати представників певної категорії, як-от інструменти чи фрукти ${ }^{18}$.

Цікавим випадком категоризації є вживання назв кольорів. Історично склалися два радикально протилежні підходи до категоризації кольорів. Крайні універсалісти наполягають, що позаяк біологічна будова людини однакова, то існують універсальні обмеження, накладені на кольоробачення. Крайній релятивізм ототожнюється 3 твердженням про цілковиту довільність категоризації кольору в різних культурах. Обидві крайні позиції на сьогодні є неприйнятними. Натомість відбувається пошук компромісної, реалістичнішої концепції, яка враховувала б якомога більше чинників, що впливають на сприйняття кольору людиною. Оригінальний компроміс у суперечці універсалістів та релятивістів запропонували американські науковці Т. Регір та П. Кей, які загалом схильні відстоювати першу позицію: універсалістам вони віддали праву півкулю мозку людини, а релятивістам - ліву. Було встановлено, що мовні категорії кольору локалізовані в лівій півкулі мозку й впливають, відповідно, на колірну категоризацію в правому візуальному полі, але не в лівому ${ }^{19}$. Це твердження підтримують

${ }^{15}$ Ibidem.

${ }^{16}$ F. G. Ashby, W. T. Maddox, Ibidem; F. G. Ashby, Ibidem.

${ }^{17}$ F. G. A shby, W. T. Maddox, Ibidem; F. G. A shby, Ibidem.

${ }^{18}$ F. G. A shby, Ibidem.

${ }^{19}$ T. Regi er, P. Kay, Language, thought, and color: Whorf was half right, [in:] „Trends in Cognitive Sciences" 2009, Vol. 13, Is. 10, pp. 439-446. 
й науковці, схильні до помірного релятивізму ${ }^{20}$. У науковій спільноті когнітивістів формується консенсусна позиція про наявність двох якісно відмінних систем оброблення інформації про колір - перцептивної й мовної. Перша в нормі локалізована в правій півкулі, а друга - в лівій. Перша оцінює колірні взірці за подібністю, сказати б, „об’єктивно”, тобто сприймає суто сенсорні дані. Мовна ж система інтерпретує сенсорну інформацію, пропускаючи іiі через фільтр усталених мовних колірних категорій і спричиняючись до так званого ефекту категорійного сприйняття. Обидві системи працюють паралельно, але на певному етапі виведення інформації верх бере система мовної категоризації. Вплив мовних колірних категорій на сприйняття кольору не викликає сумнівів.

Повищі результати нейродосліджень мають не лише велике теоретичне значення для глибшого розуміння зв'язку мови й мислення, а й знаходять практичне застосування. Вони високою мірою релевантні, наприклад, в галузі викладання чужих мов, бо спонукають шукати оптимальні шляхи подання навчального матеріалу залежно від того, яку систему категоризації студенти схильні застосовувати під час його опанування. Ці результати помічні й у лінгвістичних студіях, зокрема у вивченні колірних категорій. Ми дослідили вживання українських колоративів синій, блакитний і голубий на основі підходу, мета якого полягає у встановленні референтних взірців (еталонів, прототипів) кольору. Цей метод обгрунтувала А. Вежбицька ${ }^{21}$ й розвинули, зокрема, польські й українські науковці ${ }^{22}$. Детальний виклад результатів нашого дослідження представлено в окремій праці ${ }^{23}$, а тут подамо лише загальні висновки й обговорення у світлі даних нейронаук.

Опрацювавши широкий фактичний матеріал, ми дійшли висновку, що в таких колористичних студіях за одиницю аналізу слід обрати не об'єкти, а еталонні візуальні ситуації, тобто типові ситуації, в яких об'єкт спостережувано за певних умов. Самих взірцевих об'єктів не досить, позаяк вони можуть бути однаковими для кількох кольороназв, і тоді вирішальним чинником виявляються умови спостереження. До того ж, за мету реконструкції варто покласти встановлення цілої категоризаційної моделі, до якої може належати низка еталонних ситуацій із різним ступенем важливості. На матеріалі даних асоціативних експериментів та матеріалу електронного корпусу української мови ми встановили, що в категоризаційній моделі синьої частини спектру зі значною перевагою домінує взірець „небо”: кожен із трьох розглядуваних колоративів найтісніше пов'язаний саме з ним. На другому щаблі ієрархії стоїть взірець „повітряний простір", під яким мається на увазі маса повітря, що заповнює простір між землею і небом. На лексичному рівні номінації цього еталона можуть бути досить різними: блакитний ранок, голубі хвилі чистого повітря, синій небокрай тощо. До другорядних взірців моделі належать також „море”, інші водойми та „імла”, тобто повітря з пониженою прозорістю (напр., туман, серпанок тощо). Решта номінацій значно менш частотні або ж не утворюють однорідних груп. Якщо моделі трьох розглядуваних колоративів містять ту саму ієрархію (з незначни-

${ }^{20}$ D. Robers on, J. R. Han ley, Only half right: comment on Regier and Kay, [in:] ,Trends in Cognitive Sciences" 2009, Vol. 13, Is. 12, PP. 500-501.

${ }^{21}$ A. Wi e r z b i c ka, Semantic Primes and Universals, Oxford 1996.

${ }^{22}$ R. Gre go r c z y k ow a, K. Wa s za k ow a (red.): Studia z semantyki porównawczej, Warszawa 2000; S. Martinek, Pomarańcze i rewolucja czyli zmiany w kategoryzacji barw podstawowych, [w:] „Etnoligwistyka” 2006, Nr 18, s. 295-310.

${ }^{23}$ V. S tark o, Ukrainian Colour Concepts for Blue, [in:] „Slovo. Journal of Slavic Languages and Literatures" 2013, No. 54, PP. 150-163. 
ми відмінностями) референційних взірців, то в чому ж приховано відмінності? Ми встановили, що їхнім джерелом є аспекти еталонних візуальних ситуацій, причому ключову роль відіграє ступінь природного освітлення: блакитний має найтіснішу асоціацію 3 кольором неба в яскравий сонячний день; сфера референції голубого майже така сама, проте зв'язок із освітленістю слабший, а натомість виявляється тенденція до позначення насиченої чистої барви; синій уживають за умов і повного, і пониженого чи низького освітлення (сині смерки, синій вечір, синя ніч тощо), що й пояснює широкий діапазон охоплення відтінків цим колоративом.

Дані нейродосліджень дають змогу глибше осмислити й точніше проінтерпретувати викладені вище результати. Очевидно, що опанування колірних категорій в онтогенезі відбувається на основі категоризації за подібністю, що має покроковий, приростовий характер. Цей процес вимагає повторення численних актів категоризації, внаслідок чого відповідна ділянка нейронної мережі налаштовується так, що мовнокатегоризаційна компетенція мовця наближається до середньої й стає прийнятною в мовному колективі. Зрозуміло також, що в цих актах категоризації фігурують не лише перелічені вище взірці. Об'єктів, що $\epsilon$ „носіями” відповідних відтінків, дуже багато, й в особистому досвіді людей вони можуть бути особливими чи навіть неповторними. Іншими словами, на індивідуальному рівні категорія того чи того кольору формується в процесі взаємодії з різноманітними об'єктами в різних ситуаціях. Вони виконують роль множинних колірних взірців на рівні індивідуальної або й колективної мовної свідомості (порівн. усталені порівняння на кшталт голубий / синій як льон, синій як волошки / терен тощо). Специфікою усталених взірців можна пояснити відмінності у сфері референції відповідних кольороназв у діалектах мови. Натомість єдність та уніфікацію забезпечують еталонні ситуації, що є спільними й відносно сталими елементами досвіду всієї мовної спільноти. Вони становлять категоризаційну модель на національному рівні мовної свідомості, й саме такий тип моделі ми окреслили, описали вище стосовно синьої частини колірного спектру. Така загальна модель опановування колірних категорій ураховує відносну стійкість і водночас гнучкість системи, однорідність та відхилення.

Отже, дослідження нейронних структур мозку має велике значення для вивчення природномовної категоризації, розкриває аспекти зв'язку мови й мислення та сприяє глибшому розумінню реальних категоризаційних процесів. Зі свого боку, лінгвістичні студії показують, як механізми, що були виявлені в лабораторних умовах, працюють у живому мовному середовищі. Передбачаємо, що з часом обмін інформацією між лінгвістикою та нейронауками посилиться, що сприятиме плідним міждисциплінарним дослідженням. 